\title{
Gender stereotypes depicted in online sexist jokes
}

\author{
Anastasia Nelladia Cendra \\ Sanata Dharma University, Indonesia \\ anelladiahp@gmail.com
}

\section{Teresia Dian Triutami}

Sanata Dharma University, Indonesia teresiadian32@gmail.com

\author{
Barli Bram \\ Sanata Dharma University, Indonesia \\ barli@usd.ac.id
}

\begin{abstract}
This research aimed to explore gender stereotypes depicted in online sexist jokes collected from laughfactory.com. Linguistically speaking, jokes as a subtype of humour have become a common phenomenon in our everyday lives. Unfortunately, not all jokes can bring positive vibes for everyone. Yet, these forms of jokes are still commonly found, especially on the Internet. Some online sources, including websites of jokes, present a lot of collections of jokes for fun, but a number of the jokes are categorized as sexist jokes, which might also be regarded as offensive in a certain context. Data were collected from the laughfactory.com website and then were analysed by using the three-dimensional model of Critical Discourse Analysis (CDA) and the General Theory of Verbal Humour (GTVH). Results showed that the majority of the jokes observed were targeted at women (90\%) and a small number was targeted at men (10\%). Women were stereotyped as sexual objects, emotionally expressive beings, homemakers, being talkative, being stupid or brainless, and belonging to a lower class than men. Men, on the other hand, were stereotyped as worse than women.
\end{abstract}

Keywords: gender stereotype, General Theory of Verbal Humour (GTVH), joke, sexist, discourse analysis, laughfactory.com.

\section{Introduction}

Jokes, as a subcategory of humour, have become an inseparable part of our everyday life. People may find a great deal of jokes in their day-to-day experience. As they gain a high profile in our society, jokes and other kinds of humour can be found anywhere, from sitcoms 
on television, comedians, humorous or funny books, and even advertisements (Ross 1998). Jokes, one of the 12 subtypes of humour (Shade 1996), simply cannot be separated from our lives.

When investigating jokes, it is necessary to cover the superordinate or hypernym humour. Although it is hard to define what is meant by and what counts as humour (Attardo 1994; Ross 1998), humour certainly has many benefits for our lives. As people smile, chuckle, or laugh at a certain joke, a pleasant emotional feeling, well-being, and mirth will follow (Martin 2007: 1). Humour is also able to improve one's physical health as it enhances one's respiration, circulation, immune system, and tolerance to pain as well as reduces stress that leads to a more positive mental state (Goebel 2011). Another study also claims that humour can be "a key to controlling stress, promoting good health, and encouraging positive work relationships" (Black \& Forro 1999: 171).

Unfortunately, humour is not always funny. Not all kinds of humour can bring positive vibes to everyone. Some types of humour, such as ethnic jokes, political jokes, and gender jokes, are considered to be a more negative phenomenon (Pasaribu \& Kadarisman 2016: 23). These types of humour attack specific groups of people, and thus, may be considered inappropriate. A case in point, an ethic joke about a Turkish minority may indeed intend to bring amusement to the listeners; yet, it can also shock and insult Turks, especially when they are present in the moment the joke is told (Kuipers 2015: 9). Some political jokes told in the Soviet Union also often make fun of the individual leaders (Davies 2011: 214). Nevertheless, these forms of humour are still commonly found, especially on the Internet. For instance, a website of humour called laughfactory.com contains a huge collection of jokes. It also has one tab to provide collections of sexist or gender humour; humour which relies on gender matters to elicit people's laughter (Pasaribu \& Kadarisman 2016: 24).

Studying humour in general and jokes in particular may give us rich information about the society around us. Laineste (2008) discusses how humour has the ability to give insights about our surroundings and, thus, the standardised images of society, which are strongly related to stereotypes. Studying sexist or gender jokes, for example, will show "how creative human minds are in manipulating language, and at the same time it also tells a lot about the social aspect of the humour through stereotypical image" (Pasaribu \& Kadarisman 2016: 24), which in this case is gender stereotypes. Stereotypes can be defined as the ways people think about women and men and the prescriptions about what women and men should be (Prentice \& Carranza 2002 as cited in Brannon 2011: 167). Therefore, studying sexist jokes might give us rich explanations of how society stereotypes gender.

Unfortunately, some people argue that studying humour, including jokes, is not a good idea; it will take the joy away from humour itself. As E. B. White puts it metaphorically, examining humour is similar to dissecting a frog; not many are interested in doing it, and, once they do, the frog dies (as cited in Goebel: 2011: 1). Similarly, the famous poet W.H. Auden also argues that studying humour will kill it (as cited in Lew 1996: 6). Nevertheless, Martin (2007: 1) claims that despite the fact that humour involves a light-hearted and non-serious attitude towards something, it is still worth a scientific investigation, as humour also exhibits some serious functions in social, emotional, and cognitive matters. Furthermore, systematic studies about humour are also encouraged because humour has proven to have beneficial effects in people's lives (McGraw 2011). Conducting research on humour in clinical settings, some researchers have proven how humour can be utilised, for instance, to help induce positive emotions and reduce stress and anxiety through clown intervention (Dionigi \& Canestrari 2016), or how humour can be used as a tool for cognitive therapy (Dionigi \& Canestrari 2018).

Given the above, it is interesting to explore how jokes can be one way society describes how, by its standards, men and women should be or behave. Closely examining this matter 
will allow us to discover what kinds of gender stereotypes are injected to our everyday jokes. Hence, by examining some sexist or gender jokes found on the Internet, specifically from laughfactory.com, the present research attempts to resolve the following research question: What types of gender stereotypes are depicted in gender jokes found in laughfactory.com?

\section{Literature review}

This section discusses a brief overview of previous literature related to this study. Three parts are presented, namely gender and humour, gender stereotypes, and the General Theory of Verbal Humour (GTVH)

\subsection{Gender and humour}

Gender is built over cultural, political, and language intervention, making it a complex phenomenon (Holmes 2007: 171). Gender is an influential factor for the creation of humour, either explicitly or implicitly (Kotthoff 2006). There are at least four dimensions of humour that have been identified as sensitive to gender, namely status, aggressiveness, social alignment, and sexuality (Kotthoff 2006).

Because of gender differences, it is not surprising to see that men and women may approach humour differently. A case in point, examining spontaneous spoken-conversational humour, Hay (2000) finds that men and women tend to use humour quite differently; for instance, women tend to share their funny personal stories, whereas men tend to reminiscence shared experiences to build solidarity. Wu et al. (2016) also find that, compared to women, men tend to use unfriendly and aggressive humour. More recently, Tosun et al. (2018) also find that male figures were more likely considered as the ones embodied an "ideal" sense of humour.

Apart from how gender can influence humour styles, a gender matter itself can become the content of humour. This kind of humour is known as sexist or gender humour, which will be the focus of the present research. Briefly defined, sexist or gender humour makes use of gender matters to trigger people's laughter; it may contain people's perception or criticism on a certain topic (Pasaribu \& Kadarisman 2016: 24). Thomae \& Pina (2015) argue that gender humour is used to improve in-group cohesion while at the same time belittle the outsider group. They further discuss how gender humour tends to become a 'social lubricant' for male ingroup, while being 'social abrasive' for men and women intergroup relations (see Thomae \& Pina 2015: 201). Furthermore, as Bergmann (1986) notes, in many cultures, it is mostly women that become the object of gender jokes. Because gender jokes are considered to be a negative phenomenon, the investigation on gender humour is interesting as it demonstrates how humans can make use of language to criticise the social phenomena, particularly gender stereotypes (see Pasaribu \& Effendi 2016: 24).

\subsection{Gender stereotypes}

Prentice \& Carranza (2002) argue that gender stereotypes are highly related to society's prescriptive or common sense. Gender stereotypes divide women's and men's roles into masculine and feminine. For example, women are mostly stereotyped as warm and caring. Therefore, women are mostly required to be warm and caring. In contrast, men are labelled as strong and agentic; thus, in the real life, they should be strong and agentic. Eagly (1987) suggests that gender stereotypes are closely related to traditional social roles and power inequalities between women and men. 
In some cases, women are often stereotyped as the homemakers (Schneider \& Schneider 1979 as cited in Royo et al. 2001: 3). This stereotype is related to the Industrial Revolution in Europe during the 19th century that changed the life of most people in North America and Europe. Previously, most women and men worked together to manage their farms, but then men were forced to work outside, while women stayed at home as homemakers and took care of the children (Brannon 2011: 161). Londo (2006) also mentions that in women's magazines, women are often portrayed with a family and children (as cited in Pasaribu \& Kadarisman 2016). This portrayal leads to the belief that women are always with children and are considered to be incomplete without a family and children. Similarly, there are some other researchers who find that women are more often than men to be with children in domestic settings; they are pictured as unemployed and passive (Furnham \& Bitar 1993; Lysonksi \& Pollay 1990 as cited in Royo et.al. 2001: 3).

Royo et al. (2001: 3) also suggest that women are mostly stereotyped as sexual objects. A study of depictions of women in various media by the American Psychological Association (2007) reveals that women are more often depicted in sexualising and objectifying manners; for example, women are portrayed in such ways that emphasise their body parts (as cited in Szymanski et al. 2011). In other words, women are judged merely on the basis of their visual attractiveness to fulfil men's needs (Lisdianita 2013: 48). Shifman \& Lemish (2009) also mention that, in traditional stereotypes, and compared to men, women are often considered as sexual objects. Usually, there will be a comparison between women and another object (Lisdianita 2013: 49).

There are still many stereotypes targeted at women. For examples, historically, women were often portrayed as uncontrollable when they were against patriarchy's order (Foka 2015: 7). It means that women who were against the patriarchy or men power were often stereotyped negatively (Foka 2015: 7). Besides, women are stereotyped as dependent and oriented towards others (Eagly \& Steffen 1984; Spence \& Helmreich 1978 as cited in Cuddy et al. 2010: 3). This shows that women are often considered that they cannot be independent; they need other hands and tend to live as a group. There is also a stereotype in society about women's talkativeness (Mehl et al. 2007: 82). This stereotype is related to Western folklore, which is often considered to be a scientific fact. However, Mehl et al. (2007) found that women and men produce approximately 16,000 words a day, suggesting that the stereotype of how women are more talkative than men is incorrect.

Going further, there is also a belief that women are more emotionally expressive than the other gender (Parkins 2012: 51). Parkins' (2012) findings specifically suggest that women are more expressive in showing happiness, sadness, and fear, while men mostly express their anger. There is also another female stereotype in society, namely women as gold diggers. In the Adolescent African American Women's Sexual Scripts, for example, there is a gold digger character named Diva. These scripts are based on the true reality of how society stereotypes African American women. In those scripts a "gold digger is a woman who explicitly seeks material and economic rewards above all else, and is willing to trade sex for it" (Stephens \& Phillips 2014: 17-18).

Although there are a lot of stereotypes targeted at women, some stereotypes are targeted at men. For instance, men are often "stereotyped as independent, agentic, and goal oriented" (Eagly \& Steffen 1984; Spence \& Helmreich 1978 as cited in Cuddy et.al. 2010: 3). It means that men are often portrayed as leaders who run businesses or work in the industrial world. Therefore, men are considered in charge of the "household budget and making purchase decisions" (Verhellen et al. 2014: 3). However, the "True Womanhood" stereotype suggests that men are "at best, prone to sin and seduction, and at worst, brainless, and brutes" (as cited in Brannon 2011: 161). These show that men are not always stereotyped positively, but also negatively. 


\subsection{General Theory of Verbal Humour}

The General Theory of Verbal Humour (GTVH) can be used to analyse any form of humorous texts (Attardo 1994: 222). The GVTH can act as a framework for the linguistic analysis of humour (see Hempelmann \& Ruch 2005; Cendra 2016; Masaeli \& Heidari-Shahreza 2016). This theory has been employed to analyse humour in several previous studies, such as in decoding the language mechanism of cyber humour (Pasaribu \& Kadarisman 2016), examining language and image interaction in cartoons (Tsakona 2009), the variation of humorous representations in mass culture texts (Archakis et al. 2014), and many others. In addition, as one of the major theories of humour, several studies devoted to the GTVH were conducted, such as the one by Attardo et al. (2002) on modelling incongruities and their resolutions, Hempelmann \& Ruch (2005) who focused on interdisciplinary humour research, and Canestrari (2010) who introduced another knowledge resource to the theory, known as Meta-Knowledge Resource.

Six Knowledge Resources (KRs) are introduced by the GTVH as the parameters or attributes of humour, which may be used to make comparisons between jokes. Presented in hierarchical order, the six KRs are Script Opposition (SO), Logical Mechanism (LM), Situation (SI), Target (TA), Narrative Strategy (NS), and Language (LA). All these KRs are important parameters that should be considered when, for example, analysing joke similarities and differences (Attardo 1994: 227).

Attardo (1994) further elucidates each of these KRs. The Script Opposition (SO) KR deals with the opposition of two scripts. A script itself is defined as:

a cognitive structure internalised by the speaker which provides the speaker with information on how a given entity is structured, what are its parts and components, or how an activity is done, a relationship organised, and so on, to cover all possible relations between entities, including their constituents (Attardo 2001: 2-3).

In other words, scripts are chunks of information about something, which are organised in a certain way. SO prescribes that, a text can be considered funny, when two scripts are overlapping and opposite to one another. Language Mechanism (LM) refers to how the scripts of humour are put together so that they can evoke laughter. Situation (SI) is responsible for the situation where humour is staged; it is known as the "props" of humour. Narrative Strategy (NS) is responsible for where the many forms of narrative organisation or genres, such as a dialogue. Language (LA) deals with the exact wording of humour and the position of the punch line (see Attardo 1994: 222-226). This hierarchy of KRs is arranged based on their strength. As suggested by Attardo (1994: 227), "[p]arameters determine the parameters below themselves and are determined by those above themselves". It means that the values chosen in higher KRs will limit the options available for the lower KRs.

\section{Method}

This is a Critical Discourse Analysis (CDA) study. Jorgensen \& Philips (2002: 24) suggest that CDA is a theoretical framework that can be utilised to analyse the use of language in social practice or phenomena. Berger (2016: 4) argues that CDA can be used to understand how language constructs identities, social relationships, and the social and political world. As this study focuses on understanding gender jokes, CDA was used, since gender bias and sexism can be understood as a discourse (Weatherall 2002). Weatherall (2002: 81) further argues that humour, gender, and sexism are related to discourses and social practices. They are 
related to social phenomena, social relationships, and the social political world (Berger 2016: 4).

The data of this research were 20 sexist jokes collected from laughfactory.com in October 2017. The researchers chose the data from the most viewed sexist jokes in October 2017. The researchers collected the jokes from laughfactory.com through the Internet considering that the website is accessible and representative.

In order to gain a deep understanding of the jokes, the researchers employed Fairclough's (2003) three-dimensional model of CDA as a research method. The three stages of CDA are: description (text), interpretation, and explanation (social practice). First, in the description (text) stage, the researchers analysed the linguistic aspect of the data collected. In this stage, the researchers employed the GTVH to analyse the content of the jokes, especially the target of the jokes. Second, in the interpretation stage, the researchers made some interpretations related to how the jokes were structured to (re)produce certain gender stereotypes. Third, the researchers analysed the social practice (explanation) by looking at the relationship between the content of jokes - especially its targets - and the stereotypes of gender existing in society. Through these steps of analysis, the researchers were able to describe the stereotypes depicted in gender jokes. All the steps of analysis were conducted together by all researchers and they encountered no unsolvable disagreements throughout the research process.

\section{Findings and discussion}

This section is divided into two parts, namely joke analysis and gender stereotypes. The first section is to discuss the content of the jokes, especially the targets of the jokes, in which the results will be used to conduct a further analysis. The second section is to provide the analysis of some gender stereotypes depicted in the collected jokes.

\subsection{Joke analysis}

As stated in the method section, the researchers analysed the humorous texts by using the GTVH. The six KRs of the GTVH were used to examine these jokes. One example of analysis is presented in Table 1.

Table 1. Analysis of joke 1.

\begin{tabular}{|l|l|}
\hline \multicolumn{1}{|c|}{ Parameters } & \multicolumn{1}{c|}{ Analysis of Joke } \\
\hline Script Opposition & Crazy vs testicle \\
\hline Language Mechanism & Absurd interpretation \\
\hline Situation & $\begin{array}{l}\text { A pair of saggy boobs talk together about their } \\
\text { sagginess }\end{array}$ \\
\hline Target & Female \\
\hline Narrative Strategy & Question-and-answer dialog \\
\hline Language & $\begin{array}{l}\text { Set up: } \\
\text { Q: What did one saggy boob say to the other saggy } \\
\text { boob? } \\
\text { Punch-line: } \\
\text { A: "We better get some support before someone } \\
\text { thinks we're nuts!" }\end{array}$ \\
\hline
\end{tabular}


Using the GVTH, the content of joke 1 can be elaborated clearly. Joke 1 contrasts two different ideas, being crazy vs a man's testicles. The author of the joke makes use of the word "nuts" to create a joke through an absurd interpretation as the LM. Built on a certain situation where one pair of saggy boobs talks to one another about their sagginess, the joke is targeted at women, indicating that the boobs might be regarded as man's testicles because of their sagginess. Finally, we can see that the punch line is positioned at the end of the joke in its question-answer format.

Doing the same analysis to the rest of the data, the researchers found that the jokes are built upon many and various script oppositions and situations (see Appendix 1). Furthermore, complex language mechanisms, such as absurd interpretation, fallacious reasoning, and fallacious analogy are used in most of the jokes. Additionally, the narrative strategies used to present the jokes are mostly the short narrative and the question and answer formats.

Interestingly, the researchers observed that the jokes analysed are mostly targeted at women. Among 20 most popular gender jokes found in laughfactory.com, which become the object of this research, 18 jokes are targeted at women (90\%). Only two jokes are targeted at men (20\%). Interestingly, each of these jokes contains gender stereotypes for each gender. The next part will elaborate further what gender stereotypes are portrayed in these jokes.

\subsection{Gender stereotypes}

From the last two steps of analysis, namely the interpretation and explanation steps, it is revealed that there were many kinds of gender stereotypes depicted in the objects of this research, both for male and female. Table 2 summarises the findings of the occurrence of gender stereotypes in these jokes. The analysis of each kind of the gender stereotypes found in these jokes will be presented in this section, starting from the most frequent occurrences. The less frequent occurring stereotypes are also discussed in this section.

Table 2. Summary of the gender stereotype occurrence.

\begin{tabular}{|c|l|c|c|}
\hline Gender & Stereotype & $\begin{array}{c}\text { Number of } \\
\text { Occurrences }\end{array}$ & Percentage \\
\hline \multirow{3}{*}{ Women } & Man's sex objects & 5 & $25 \%$ \\
\cline { 2 - 4 } & Emotionally expressive & 4 & $10 \%$ \\
\cline { 2 - 4 } & Homemakers & 3 & $15 \%$ \\
\cline { 2 - 4 } & Gold diggers & 3 & $15 \%$ \\
\cline { 2 - 4 } & Talkative & 1 & $5 \%$ \\
\cline { 2 - 4 } & Brainless beings & 1 & $5 \%$ \\
\cline { 2 - 4 } & $\begin{array}{l}\text { Belonging to a lower class } \\
\text { than men }\end{array}$ & 1 & $5 \%$ \\
\hline Men & Worse than women & 2 & $10 \%$ \\
\hline
\end{tabular}

\subsubsection{Women as men's sexual objects}

The stereotype of women as men's sex objects (Royo et al. 2001: 3) becomes the most frequent stereotypes portrayed in the object of this research, with five occurrences. In these jokes, women's body parts are emphasised to attract men's sexual arousal or pleasure. Joke 2 is presented here for analysis.

(2) A man is being arrested by a female police officer, who informs him, "Anything you say can and will be held against you". The man replies, "Boobs!" 
Joke 2 involves a situation where a female police officer arrests a man. While arresting him, the female police officer says "Anything you say can and will be held against you", trying to remind him that everything he says can be used to prove him guilty and, thus, he should be careful. However, as the punchline, the man shouts "boobs", indicating that he absurdly assumes that he would get the chance to hold and touch anything he mentions, including the police officer's boobs. This joke indicates a stereotype where women's body parts are exploited for the sake of men's pleasure.

Similarly, joke 3 depicts how women become a man's sex object, where their visually attractive body could attract men's sexual desire, as follows.

(3) A man is lying on the beach, wearing nothing but a cap over his crotch. A woman passing by remarks, "If you were any sort of a gentleman, you would lift your hat to a lady". He replies, "If you were any sort of a sexy lady, the hat would lift by itself".

Joke 3 is set on the beach where a man is lying down almost naked, except that there is a hat over his crotch, when a woman passes by. The woman mentions that he should have raised his hat to give her salute if he were a gentleman. As a punchline, he snaps back saying how the hat would raise by itself as he would have experienced erection if she were sexy - in which, we could infer, she is not. The joke implicitly shows that women's sexiness is an indicator of a men's arousal. Thus, the stereotypes of women being men's sexual objects is clearly portrayed in this joke.

\subsubsection{Women as emotionally expressive beings}

There are four jokes featuring the stereotype of women as emotionally expressive beings. Parkins (2012: 51) mentions that there is a stereotype in society that, compared to other genders, women tend to be more emotionally expressive. Joke 4 portrays this stereotype (see appendix 2 for complete list of gender stereotypes depicted in these jokes).

(4) How did the medical community come up with the term "PMS"?

"Mad Cow Disease" was already taken.

Related to joke 4, PMS (Premenstrual Syndrome) refers to the condition most women experience before getting their period. When a woman is experiencing PMS, she would likely feel more sensitive compared to the way she usually is. Joke 4 makes use of this fact and exaggerates the effect of PMS by ludicrously comparing it to mad cow disease to evoke laughter. As a result, how women are stereotyped as sensitive and emotionally expressive beings is portrayed in this joke.

\subsubsection{Women as homemakers}

The researchers observed three jokes which stereotype women as homemakers; they stay at home and have the responsibility to take care of the children and manage households (Brannon 2011: 160). Joke 5, for instance, clearly portrays this stereotype.

(5) A man driving a car hits a woman. Whose fault is it?

The man's. Why was he driving in the kitchen?

Joke 5 presents in a situation where a man who is driving a car hits a woman. Then someone asks, whose fault that is, and the answer is the man's. Before getting to the punchline, one might think that the man is so careless in driving his car in the street that he accidently hits the woman. However, at the end, the joke is twisted by a rhetorical question, "why was he driving in the kitchen?", indicating the only possibility of where a woman can be is in the kitchen. 
Another joke that portrays women as responsible for household chores is the following one.

(6) As an airplane is about to crash, a female passenger jumps up frantically and announces, "If I'm going to die, I want to die feeling like a woman". She removes all her clothing and asks, "Is there someone on this plane who is man enough to make me feel like a woman?" A man stands up, removes his shirt and says, "Here, iron this!".

Joke 6 presents a situation in an airplane that is about to crash. Being known that her death is near, a woman challenges a man to have sex with her, indicated by the way she removes all her clothes, saying "I want to die feeling like a woman". When a man stands up and also removes his shirt, one might expect that he wants to have sex with the woman. Instead, as the twist reveals, the man asks the woman to iron his shirt, suggesting that "feeling like a woman" means doing chores for him.

\subsubsection{Women as gold diggers}

Women as gold diggers became another stereotype the researchers observed. "Gold digger is a woman who explicitly seeks material and economic rewards above all else, and is willing to trade sex for it" (Stephens \& Phillips 2014: 17-18). In other words, gold diggers refer to women who are very materialistic and money driven. There are three jokes that stereotype women as gold diggers (see Appendix 2 for a complete list of gender stereotypes depicted in these jokes). An example is taken from joke 7, as follows.

(7) Q: When can women make you a millionaire?

A: When you're a billionaire.

Joke 7 begins with a question about when a woman can make a man a millionaire. Related to this joke, there is a famous quote saying, "there is always a woman behind in every man's success". Yet, the punch line of the joke shows that a woman can make a man a millionaire if only he is a billionaire, suggesting that the woman will give the man only a million and keep the rest of the wealth. The joke is considered to be sexist, because this joke stereotypes women as gold diggers, who benefit from men. This joke indicates how women cannot make men successful; in contrast, all they can do is spend men's money.

Another example is taken from joke 8, as follows.

(8) What's six inches long, two inches wide, and drives women wild? Money.

In this joke, one might guess that six inches long, two inches wide, and drives women wild is a penis. However, the punchline reveals that the answer is money. The punchline obviously shows a stereotype that women are more interested in material resources, such as money, than in other things.

\subsubsection{Other women stereotypes}

The researchers also found that there are other women stereotypes, namely women as talkative, and brainless persons and belonging to a lower class than men (see Mehl et al. 2007; Cuddy et al. 2010; Foka 2015) in the data examined. For example, joke 9 compares women and Google as a machine who likes to make suggestions:

(9) Q: Is Google male or female?

A: Female, because it doesn't let you finish a sentence before making a suggestion. 
Joke 9 indicates how women are stereotyped to be more talkative than men. This stereotype can be seen from the punch line which implies that a woman will never let anyone finish their sentences before making a suggestion. Therefore, this joke stereotypes how a female is supposed to be more talkative.

Besides, the researchers also found that women are stereotyped as belonging to a lower class than men. Joke 10 is presented here.

(10) An investigative journalist went to Afghanistan to study the culture and was shocked to discover that women were made to walk ten paces behind the men. She asked her guide why and he said, "Because they are considered of lesser status". Outraged the journalist went home. A year later she returned covering violence in the region and was surprised to see the women walking ten paces ahead. She turned to her guide and this time asked, "What has changed?" The guide answered, "Land mines".

Joke 10 shows a situation where an investigative journalist went to Afghanistan to study the culture and was shocked about the fact that the women there walked 10 paces behind men and he asked why. However, a year later, when he came back, he found that women walked ten paces ahead than men. He then questioned what has changed and the answer was landmines. From the script opposition and the punch line, we can see that instead of having gender equality as readers may expect, women are used as a bait to keep men safe from landmines. It shows how women are still considered to belong to a lower class than men. Even in the gender equality era, in some cultures women are still having lower power than men, particularly in patriarchal cultures (Foka 2015: 7).

Furthermore, women are portrayed as brainless or stupid. Joke 11 depicts this stereotype.

(11) How do you know when a woman is about to say something smart? When she starts her sentence with, "A man once told me..."

In joke 11, someone asks about how to identify a smart woman and the punch line is "when she starts her sentence with, 'A man once told me..."”. This joke portrays women as stupid beings, as they are not able to say something smart without having a man told them before. In this joke, women are stereotyped that they cannot be smart without men.

\subsubsection{Men as worse than women}

The researchers found that jokes targeted at men are less frequent than jokes targeted at women. As summarised in Table 2, there are only two jokes that use men as their butts. Related to this, indeed, it has been noted that men are often "stereotyped as independent, agentic, and goal oriented" (Eagly \& Steffen 1984; Spence \& Helmreich 1978 as cited in Cuddy et al. 2010: 3). However, both jokes targeting men here show how men are considered worse than women. Joke 12, for example, shows this stereotype.

(12) Girl: "Girls are better than boys".

Boy: "Then why did God make boys first?"

Girl: "Duh, you have to have a rough draft before the final copy".

Joke 12 clearly portrays men as a rough draft, which means that men are the first experiment and they need improvement. In other words, this joke indicates that women are better than men because woman is the final result/product of a rough draft. Although sometimes women are considered of lower status than men, this joke clearly stereotypes that women are better than men. 


\section{Conclusion}

The present research brings forth an empirical evidence related to gender jokes and the stereotypes they portray. Most of the 20 jokes, which were collected laughfactory.com, were targeted at women $(90 \%)$. Only a small number was targeted at men $(10 \%)$. It therefore seems that, in the context of this research, women were more frequently used as the target of gender jokes than men. Each of this joke also portrayed gender stereotypes which have been previously discussed in the literature. In these jokes, women were stereotyped as men's sex objects, homemakers, gold diggers, or emotionally expressive beings. Moreover, other women stereotypes such as women as talkative, brainless, and belonging to a lower class than men were also observed in the jokes. Meanwhile, in some jokes, men were stereotyped as worse than women.

This study also has some limitations. First, this study focused only on the sexist jokes which were related to women and men. Meanwhile, there were other genders that were used in the sexist jokes. Second, the research only focused on the targets' stereotypes depicted in each joke. It cannot be denied, however, that in a single joke, more than one stereotype can be depicted, both for the target of the joke as well as the attacker. For example, in the jokes in which women (the targets) were portrayed as sex objects, men (the attackers) can also be portrayed as perverts. Third, only a small number of jokes were involved in this research, which made this research ungeneralisable. Nevertheless, this research has widened the knowledge about jokes and their connection to gender stereotypes and provided a better understanding of sociolinguistic phenomena.

\section{Acknowledgements}

We would like to express our gratitude to the editors of European Journal of Humour Research and the anonymous reviewers for their kind assistance and constructive comments.

\section{Appendix}

Appendix 1. List of humour structure analysis.

\begin{tabular}{|c|c|}
\hline Parameters & Analysis of joke 1 \\
\hline Script Opposition & Crazy vs testicle \\
\hline Language Mechanism & Absurd interpretation \\
\hline Situation & A pair of saggy boobs talk together about their sagginess \\
\hline Target & Female \\
\hline Narrative Strategy & Question and answer \\
\hline Language & $\begin{array}{c}\text { Set up: } \\
\end{array}$ \\
& A: "We better get some support before someone \\
& thinks we're nuts!" \\
\hline
\end{tabular}




\begin{tabular}{|c|c|}
\hline Parameters & Analysis of joke 2 \\
\hline Script Opposition & Indicting vs touching \\
\hline Language Mechanism & Absurd interpretation \\
\hline Situation & A men is being arrested by a female officer \\
\hline Target & Female \\
\hline Narrative Strategy & $\begin{array}{c}\text { Short narrative } \\
\text { Language }\end{array}$ \\
\hline $\begin{array}{c}\text { Set-up: } \\
\text { A man is being arrested by a female police officer, who } \\
\text { informs him, "Anything you say can and will be held } \\
\text { against you." } \\
\text { Punch-line: }\end{array}$ \\
The man replies, "Boobs!" \\
\hline
\end{tabular}

\begin{tabular}{|c|c|}
\hline Parameters & Analysis of joke 3 \\
\hline Script Opposition & Salute vs erection \\
\hline Language Mechanism & Fallacious reasoning \\
\hline Situation & A female is passing by a man lying almost naked on the \\
beach
\end{tabular}

\begin{tabular}{|c|c|}
\hline Parameters & Analysis of joke 4 \\
\hline Script Opposition & Women period vs mad cow disease \\
\hline Language Mechanism & Absurd neologism \\
\hline Situation & Someone is asking about how the word PMS comes up \\
\hline Target & Female \\
\hline
\end{tabular}




\begin{tabular}{|c|c|} 
Narrative Strategy & Question and answer \\
\hline Language & Set-up: \\
& How did the medical community come up with the term \\
"PMS"? \\
Punch-line: \\
"Mad Cow Disease" was already taken. \\
\hline
\end{tabular}

\begin{tabular}{|c|c|}
\hline Parameters & Analysis of joke 5 \\
\hline Script Opposition & On the street vs in the kitchen \\
\hline Language Mechanism & Fallacious reasoning \\
\hline Situation & A man hits a woman while driving \\
\hline Target & Women \\
\hline Narrative Strategy & Question and answer \\
\hline Language & $\begin{array}{c}\text { Set-up: } \\
\end{array}$ \\
& A man driving a car hits a woman. Whose fault is it? The \\
man's. & Punch-line: \\
& Why was he driving in the kitchen? \\
\hline
\end{tabular}

\begin{tabular}{|c|c|}
\hline Parameters & Analysis of joke 6 \\
\hline Script Opposition & Having sex vs doing chores \\
\hline Language Mechanism & Fallacious reasoning \\
\hline Situation & Within an airplane which is about to crash \\
\hline Target & Female \\
\hline Narrative Strategy & Question and answer \\
\hline Language & $\begin{array}{c}\text { Set-up: } \\
\text { As an airplane is about to crash, a female passenger } \\
\text { jumps up frantically and announces, "If I'm going to die, } \\
\text { I want to die feeling like a woman." She removes all her } \\
\text { clothing and asks, "Is there someone on this plane who is } \\
\text { man enough to make me feel like a woman?" A man } \\
\text { stands up, removes his shirt and says, } \\
\text { Punch-line: } \\
\text { "Here, iron this!". }\end{array}$ \\
\hline
\end{tabular}




\begin{tabular}{|c|c|}
\hline Parameters & Analysis of joke 7 \\
\hline Script Opposition & Generous women vs gold digger \\
\hline Language Mechanism & Fallacious reasoning \\
\hline Situation & Someone asked how women made a millionaire man \\
\hline Target & Female \\
\hline Narrative Strategy & Question and answer \\
\hline Language & $\begin{array}{c}\text { Set-up: } \\
\end{array}$ \\
& Q: When can women make you a millionaire? \\
Punch-line: \\
A: When you're a billionaire
\end{tabular}

\begin{tabular}{|l|l|}
\hline \multicolumn{1}{|c|}{ Parameters } & \multicolumn{1}{c|}{ Analysis of joke 8 } \\
\hline Script Opposition & Money vs penis \\
\hline Language Mechanism & False analogy \\
\hline Situation & Someone asked what drove women wild \\
\hline Target & Women \\
\hline Narrative Strategy & \begin{tabular}{l} 
Question and answer \\
\hline Language
\end{tabular} \\
$\begin{array}{l}\text { Set-up: } \\
\text { What's six inches long, two inches wide, and drives } \\
\text { women wild? } \\
\text { Punch-line: } \\
\text { Money. }\end{array}$ \\
\hline
\end{tabular}

\begin{tabular}{|c|c|}
\hline Parameters & Analysis of joke 9 \\
\hline Script Opposition & Machine suggestion vs talk-active being \\
\hline Language Mechanism & Fallacious analogy \\
\hline Situation & Female \\
\hline Target & Question and answer \\
\hline Narrative Strategy & Comsidering what Google's gender is \\
\hline
\end{tabular}




\begin{tabular}{|c|c|}
\hline Language & $\begin{array}{c}\text { Set-up: } \\
\text { Q: Is Google male or female? } \\
\text { Punch-line: } \\
\text { A: Female, because it doesn't let you finish a sentence } \\
\text { before making a suggestion. }\end{array}$ \\
\hline Parameters & Analysis of joke 10 \\
\hline Script Opposition & Gender equity vs bait \\
\hline Language Mechanism & Fallacious reasoning \\
\hline Situation & $\begin{array}{l}\text { An investigative journalist went to Afghanistan to study } \\
\text { the culture and was shocked about the women. }\end{array}$ \\
\hline Target & Female \\
\hline Narrative Strategy & Short narrative \\
\hline Language & $\begin{array}{l}\text { Set-up: } \\
\text { An investigative journalist went to Afghanistan to study } \\
\text { the culture and was shocked to discover that women were } \\
\text { made to walk ten paces behind the men. She asked her } \\
\text { guide why and he said, "Because they are considered of } \\
\text { lesser status." Outraged the journalist went home. A year } \\
\text { later she returned covering violence in the region and was } \\
\text { surprised to see the women walking ten paces ahead. She } \\
\text { turned to her guide and this time asked, } \\
\text { Punch-line: } \\
\text { "What has changed?" The guide answered, "Land } \\
\text { mines." }\end{array}$ \\
\hline
\end{tabular}

\begin{tabular}{|c|c|}
\hline Parameters & Analysis of joke 11 \\
\hline Script Opposition & Being smart vs imitating \\
\hline Language Mechanism & Fallacious reasoning \\
\hline Situation & Someone asks how to identify a smart woman. \\
\hline Target & Female \\
\hline Narrative Strategy & $\begin{array}{c}\text { Question and answer } \\
\text { Language }\end{array}$ \\
\hline How do you know when a woman is about to say \\
something smart? When she starts her sentence with, \\
Punch-line: \\
"A man once told me..."
\end{tabular}




\begin{tabular}{|c|c|}
\hline Parameters & Analysis of joke 12 \\
\hline Script Opposition & Paper vs first creation \\
\hline Language Mechanism & Fallacious reasoning \\
\hline Situation & The first creation \\
\hline Target & Male \\
\hline Narrative Strategy & Short narrative \\
\hline Language & $\begin{array}{c}\text { Set-up: } \\
\text { Girl: "Girls are better than boys." } \\
\text { Boy: "Then why did God make boys first?" } \\
\text { Punch-line: } \\
\text { Girl: "Duh, you have to have a rough draft before the } \\
\text { final copy." }\end{array}$ \\
\hline
\end{tabular}

\begin{tabular}{|c|c|}
\hline Parameters & Analysis of joke 13 \\
\hline Script Opposition & Woman's private parts vs holes in golf \\
\hline Language Mechanism & Absurd interpretation \\
\hline Situation & $\begin{array}{l}\text { A woman was stung by a bee between the first and } \\
\text { second hole in a when playing golf }\end{array}$ \\
\hline Target & Female \\
\hline Narrative Strategy & Short narrative \\
\hline Language & $\begin{array}{c}\text { Set-up: } \\
\text { A young woman was taking golf lessons and had just } \\
\text { started playing her first round of golf when she suffered a } \\
\text { bee sting. Her pain was so intense that she decided to } \\
\text { return to the clubhouse for medical assistance. The golf } \\
\text { pro saw her heading back and said, "You are back early, } \\
\text { what's wrong?" "I was stung by a bee!" she said. } \\
\text { "Where?" he asked. "Between the first and second hole." } \\
\text { she replied. He nodded and said, " } \\
\text { Punch-line: } \\
\text { Your stance is far too wide." }\end{array}$ \\
\hline
\end{tabular}

\begin{tabular}{|c|c|}
\hline Parameters & Analysis of joke 14 \\
\hline Script Opposition & Love vs ignorance \\
\hline Language Mechanism & Fallacious reasoning \\
\hline Situation & A man asks God about the reason He made woman that \\
\hline
\end{tabular}




\begin{tabular}{|c|c|}
\hline Target & way \\
\hline Narrative Strategy & Female \\
\hline Language & $\begin{array}{c}\text { Short narrative } \\
\text { Set-up: } \\
\text { A man asks, "God, why did you make woman so } \\
\text { beautiful?" God responded,"So you would love her." } \\
\text { The man asks, } \\
\text { Punch-line: } \\
\text { "But God, why did you make her so dumb?" God } \\
\text { replied, "So she would love you." }\end{array}$ \\
\hline
\end{tabular}

\begin{tabular}{|c|c|}
\hline Parameters & Analysis of joke 15 \\
\hline Script Opposition & Cooking vs murdering \\
\hline Language Mechanism & Fallacious reasoning \\
\hline Situation & Someone is trying to reminds guys that a woman can be \\
scary too
\end{tabular}

\begin{tabular}{|c|c|}
\hline Parameters & Analysis of joke 16 \\
\hline Script Opposition & Women vs tornadoes \\
\hline Language Mechanism & False analogy \\
\hline Situation & Someone asked how women and tornadoes alike. \\
\hline Target & Female \\
\hline Narrative Strategy & Question and answer \\
\hline Language & $\begin{array}{c}\text { Set-up: } \\
\text { How are women and tornadoes alike? } \\
\text { Punch-line: }\end{array}$ \\
& $\begin{array}{c}\text { They both moan like hell when they come, and take } \\
\text { the house when they leave. }\end{array}$ \\
\hline
\end{tabular}




\begin{tabular}{|c|c|}
\hline Parameters & Analysis of joke 17 \\
\hline Script Opposition & Peace vs jealousy \\
\hline Language Mechanism & Fallacious reasoning \\
\hline Situation & $\begin{array}{l}\text { If the countries was run by women, there will be a bunch } \\
\text { of jealous countries }\end{array}$ \\
\hline Target & Female \\
\hline Narrative Strategy & Short narrative \\
\hline Language & $\begin{array}{l}\text { Set-up: } \\
\text { Everyone says the world would be better off if it was run } \\
\text { by women. Sure, maybe there wouldn't be violence and } \\
\text { territorial conquests fueled by male testosterone. But } \\
\text { instead, } \\
\text { Punch-line: } \\
\text { we'd have a bunch of jealous countries that aren't } \\
\text { talking to each other. }\end{array}$ \\
\hline
\end{tabular}

\begin{tabular}{|c|c|}
\hline Parameters & Analysis of joke 18 \\
\hline Script Opposition & Jobs vs acronym \\
\hline Language Mechanism & Absurd neologism \\
\hline Situation & There were 3 men and a woman talking about their jobs. \\
\hline Target & Female \\
\hline Narrative Strategy & $\begin{array}{c}\text { Short narrative } \\
\text { Language }\end{array}$ \\
\hline $\begin{array}{c}\text { Shree guys and a lady were sitting at the bar talking } \\
\text { about their professions. The first guy says, "I'm a } \\
\text { YUPPIE. You know, young, urban, professional." The } \\
\text { second guy says, "I'm a DINK. You know, double } \\
\text { income, no kids." The third guy says, "I'm a RUB. You } \\
\text { know, rich urban biker." They turn to the woman and } \\
\text { ask, "So what are you?" The woman replies, } \\
\text { Punch-line: } \\
\text { "I'm a WIFE. You know - Wash, Iron, F***, Etc." }\end{array}$ \\
\hline
\end{tabular}

\begin{tabular}{|c|c|}
\hline Parameters & Analysis of joke 19 \\
\hline Script Opposition & Food vs wedding \\
\hline Language Mechanism & Fallacious reasoning \\
\hline
\end{tabular}




\begin{tabular}{|c|c|} 
Situation & $\begin{array}{c}\text { Set-up: } \\
\text { Target }\end{array}$ \\
\hline Narrative Strategy & Female \\
\hline Language & Short narrative \\
\hline & $\begin{array}{c}\text { Set-up: } \\
\text { drive is decreased }\end{array}$ \\
\hline Scientists have discovered a food that diminishes a \\
woman's sex drive by $90 \%$. \\
Punch-line: \\
It's called a wedding cake.
\end{tabular}

\begin{tabular}{|c|c|}
\hline Parameters & Analysis of joke 20 \\
\hline Script Opposition & Full stop vs PMS \\
\hline Language Mechanism & Absurd interpretation \\
\hline Situation & Someone insists that joking about PMS is not funny \\
\hline Target & Female \\
\hline Narrative Strategy & (Very) short narrative \\
\hline Language & $\begin{array}{c}\text { Set-up: } \\
\text { PMS jokes aren't funny. } \\
\text { Punch-line: } \\
\text { Period. }\end{array}$ \\
\hline
\end{tabular}

Appendix 2. Target and stereotype.

\begin{tabular}{|c|c|c|c|}
\hline No. & Jokes & $\begin{array}{c}\text { Target } \\
\text { (M/F) }\end{array}$ & Stereotypes \\
\hline 1 & $\begin{array}{c}\text { Q: What did one saggy boob say to the other saggy boob? } \\
\text { A: "We better get some support before someone thinks } \\
\text { we're nuts!" }\end{array}$ & $\mathrm{F}$ & $\begin{array}{c}\text { men's sex } \\
\text { object }\end{array}$ \\
\hline 2 & $\begin{array}{c}\text { A man is being arrested by a female police officer, who } \\
\text { informs him, "Anything you say can and will be held against } \\
\text { you." The man replies, "Boobs!" }\end{array}$ & $\mathrm{F}$ & $\begin{array}{c}\text { men's sex } \\
\text { object }\end{array}$ \\
\hline 3 & $\begin{array}{c}\text { A man is lying on the beach, wearing nothing but a cap over } \\
\text { his crotch. A woman passing by remarks, "If you were any } \\
\text { sort of a gentleman, you would lift your hat to a lady." He } \\
\text { replies, "If you were any sort of a sexy lady, the hat } \\
\text { would lift by itself." }\end{array}$ & $\mathrm{F}$ & $\begin{array}{c}\text { men's sex } \\
\text { object }\end{array}$ \\
\hline 4 & $\begin{array}{c}\text { How did the medical community come up with the term } \\
\text { "PMS"? "Mad Cow Disease" was already taken. }\end{array}$ & $\mathrm{F}$ & $\begin{array}{c}\text { emotionally } \\
\text { expressive }\end{array}$ \\
\hline 5 & $\begin{array}{c}\text { A man driving a car hits a woman. Whose fault is it? The } \\
\text { man's. Why was he driving in the kitchen? }\end{array}$ & $\mathrm{F}$ & homemaker \\
\hline 6 & As an airplane is about to crash, a female passenger jumps & $\mathrm{F}$ & homemaker \\
\hline
\end{tabular}




\begin{tabular}{|c|c|c|c|}
\hline No. & Jokes & $\begin{array}{l}\text { Target } \\
\text { (M/F) }\end{array}$ & Stereotypes \\
\hline & $\begin{array}{l}\text { up frantically and announces, "If I'm going to die, I want to } \\
\text { die feeling like a woman." She removes all her clothing and } \\
\text { asks, "Is there someone on this plane who is man enough to } \\
\text { make me feel like a woman?" A man stands up, removes his } \\
\text { shirt and says, "Here, iron this!". }\end{array}$ & & \\
\hline 7 & $\begin{array}{l}\text { Q: When can women make you a millionaire? A: When } \\
\text { you're a billionaire. }\end{array}$ & $\mathrm{F}$ & gold-digger \\
\hline 8 & $\begin{array}{l}\text { What's six inches long, two inches wide, and drives women } \\
\text { wild? Money. }\end{array}$ & $\mathrm{F}$ & gold-digger \\
\hline 9 & $\begin{array}{l}\text { Q: Is Google male or female? } \\
\text { A: Female, because it doesn't let you finish a sentence } \\
\text { before making a suggestion. }\end{array}$ & $\mathrm{F}$ & talkative \\
\hline 10 & $\begin{array}{l}\text { An investigative journalist went to Afghanistan to study the } \\
\text { culture and was shocked to discover that women were made } \\
\text { to walk ten paces behind the men. She asked her guide why } \\
\text { and he said, "Because they are considered of lesser status." } \\
\text { Outraged the journalist went home. A year later she returned } \\
\text { covering violence in the region and was surprised to see the } \\
\text { women walking ten paces ahead. She turned to her guide and } \\
\text { this time asked, "What has changed?" The guide } \\
\text { answered, "Land mines." }\end{array}$ & $\mathrm{F}$ & $\begin{array}{l}\text { having lower } \\
\text { class }\end{array}$ \\
\hline 11 & $\begin{array}{c}\text { How do you know when a woman is about to say something } \\
\text { smart? When she starts her sentence with, "A man once } \\
\text { told me..." }\end{array}$ & $\mathrm{F}$ & $\begin{array}{l}\text { brainless } \\
\text { being }\end{array}$ \\
\hline 12 & $\begin{array}{c}\text { Girl: "Girls are better than boys." } \\
\text { Boy: "Then why did God make boys first?" } \\
\text { Girl: "Duh, you have to have a rough draft before the } \\
\text { final copy." }\end{array}$ & $\mathrm{M}$ & $\begin{array}{l}\text { worse than } \\
\text { women }\end{array}$ \\
\hline 13 & $\begin{array}{l}\text { A young woman was taking golf lessons and had just started } \\
\text { playing her first round of golf when she suffered a bee sting. } \\
\text { Her pain was so intense that she decided to return to the } \\
\text { clubhouse for medical assistance. The golf pro saw her } \\
\text { heading back and said, "You are back early, what's wrong?" } \\
\text { "I was stung by a bee!" she said. "Where?" he asked. } \\
\text { "Between the first and second hole." she replied. He nodded } \\
\text { and said, "Your stance is far too wide." }\end{array}$ & $F$ & $\begin{array}{c}\text { men's sex } \\
\text { object }\end{array}$ \\
\hline 14 & $\begin{array}{l}\text { A man asks, "God, why did you make woman so beautiful?" } \\
\text { God responded,"So you would love her." The man asks, } \\
\text { "But God, why did you make her so dumb?" God } \\
\text { replied, "So she would love you." }\end{array}$ & $\mathrm{M}$ & $\begin{array}{l}\text { worse than } \\
\text { women }\end{array}$ \\
\hline 15 & $\begin{array}{l}\text { For all the guys who think a woman's place is in the kitchen, } \\
\text { remember that's where the knives are kept. }\end{array}$ & $\mathrm{F}$ & $\begin{array}{c}\text { emotionally } \\
\text { expressive }\end{array}$ \\
\hline 16 & $\begin{array}{l}\text { How are women and tornadoes alike? They both moan like } \\
\text { hell when they come, and take the house when they leave. }\end{array}$ & $\mathrm{F}$ & gold-digger \\
\hline 17 & $\begin{array}{l}\text { Everyone says the world would be better off if it was run by } \\
\text { women. Sure, maybe there wouldn't be violence and } \\
\text { territorial conquests fueled by male testosterone. But instead, } \\
\text { we'd have a bunch of jealous countries that aren't } \\
\text { talking to each other. }\end{array}$ & $\mathrm{F}$ & $\begin{array}{c}\text { emotionally } \\
\text { expressive }\end{array}$ \\
\hline 18 & $\begin{array}{l}\text { Three guys and a lady were sitting at the bar talking about } \\
\text { their professions. The first guy says, "I'm a YUPPIE. You } \\
\text { know, young, urban, professional." The second guy says, }\end{array}$ & $\mathrm{F}$ & homemaker \\
\hline
\end{tabular}




\begin{tabular}{|c|c|c|c|}
\hline No. & Jokes & $\begin{array}{c}\text { Target } \\
\text { (M/F) }\end{array}$ & Stereotypes \\
\hline & $\begin{array}{c}\text { "I'm a DINK. You know, double income, no kids." The third } \\
\text { guy says, "I'm a RUB. You know, rich urban biker." They } \\
\text { turn to the woman and ask, "So what are you?" The woman } \\
\text { replies, "I'm a WIFE. You know - Wash, Iron, F***, } \\
\text { Etc." }\end{array}$ & F & $\begin{array}{c}\text { men's sex } \\
\text { object }\end{array}$ \\
\hline 19 & $\begin{array}{c}\text { Scientists have discovered a food that diminishes a woman's } \\
\text { sex drive by 90\%. It's called a wedding cake. }\end{array}$ & F & $\begin{array}{c}\text { emotionally } \\
\text { expressive }\end{array}$ \\
\hline 20 & PMS jokes aren't funny. Period. & & \\
\hline
\end{tabular}

\section{References}

American Psychological Association. (2007). 'Guidelines for psychological practice with girls and women'. American Psychologist 62, pp. 949-979.

Archakis, A., Lampropoulou, S., Tsakona, V., \& Tsami, V. (2014). 'Linguistic varieties in style: Humorous representations in Greek mass culture texts'. Discourse, Context \& Media 3, pp. 46-55.

Attardo, S. (1994). Linguistic Theories of Humour. London: Mouton de Gruyter.

Attardo, S. (2001). Humorous Texts: A Semantic and Pragmatic Analysis. Berlin: Mouton de Gruyter.

Attardo, S., Hempelmann, C. F., \& Di Maio, S. (2002). 'Script oppositions and logical mechanisms: Modeling incongruities and their resolutions'. Humour: International Journal of Humour Research 15 (1), pp. 3-46. https://doi.org/10.1515/humr.2002.004

Berger, A. A. (2016). Applied Discourse Analysis: Popular Culture, Media and Everyday Life. San Francisco: Acid-free Paper.

Bergmann, M. (1986). 'How many feminists does it take to make a joke? Sexist humour and what's wrong with it'. Hypatia 1 (1), pp. 63-82.

Black, L., \& Forro, D. (1999). 'Humour in the academic library: You must be joking! Or, how many academic librarians does it take to change a lightbulb?' College \& Research Libraries 60, pp. 165-172. Retrieved from http://crl.acrl.org/index.php/crl/article/view/15276/16722.

Brannon, L. (2011). Gender: Psychological Perspectives (6th ed.). London: Pearson.

Canestrari, C. (2010). 'Meta-communicative signals and humorous verbal interchanges: A case study'. Humour: International Journal of Humour Research 23 (3), pp. 327-349. https://doi.org/10.1515/HUMR.2010.015

Cendra, A. (2016). A linguistic analysis of verbal humour found in BBC Radio Drama Series Cabin Pressure: Abu Dhabi. Undergraduate Thesis, Sanata Dharma University, Yogyakarta.

Cuddy, A. J., Crotty, S., Chong, J., \& Norton, M. I. (2010). Men as cultural ideals: How culture shapes gender stereotypes. Working Paper. Retrieved from http://www.hbs.edu/faculty/Pages/item.aspx?num=37849.

Davies, C. (2011). Jokes and Targets. Bloomington, IN: Indiana University Press.

Dionigi, A., \& Canestrari, C. (2016). 'Clowning in health care settings: The point of view of adults'. Europe's Journal of Psychology 12 (3), pp. 473-488. https://doi.org/10.5964/ejop.v12i3.1107.

Dionigi, A., \& Canestrari, C. (2018). 'The use of humour by therapists and clients in cognitive therapy'. European Journal of Humour Research 6 (3), pp. 50-67. https://doi.org/http://dx.doi.org/10.7592/EJHR2018.6.3.dionigi. 
Eagly, A. H. (1987). Sex Differences in Social Behaviour: A Social-Role Interpretation. Hillsdale, NJ: Erlbaum.

Eagly, A., H. \& Steffen, V., J. (1984). 'Gender stereotypes stem from the distribution of women and men into social roles'. Journal of Personality and Social Psychology 46 (4), pp. 735-754.

Fairclough, N. (2003). Analysing Discourse: Textual Analysis for Social Research. London: Routledge.

Foka, A. (2015). 'Gender subversion and the early Christian east: Reconstructing the Byzantine comic mime', in Foka, A. \& Liliequist, J. (eds.), Laughter, Humour, and the (Un)making of Gender: Historical and Cultural Perspective. New York: St. Martin's Press, pp. 65-84.

Furnham, A., \& Bitar, N. (1993). 'The stereotyped portrayal of men and women in British television advertisement'. Sex Roles 29 (3/4), pp. 297-310.

Goebel, B. (2011). Humour Writing: Activities for the English Classroom. Urbana, IL: National Council of Teachers of English.

Hay, J. (2000). 'Functions of humour in the conversations of men and women'. Journal of Pragmatics 32 (6), pp. 709-742. https://doi.org/10.1016/S0378-2166(99)00069-7.

Hempelmann, C. F., \& Ruch, W. (2005). '3 WD meets GTVH: Breaking the ground for interdisciplinary humour research'. Humour: International Journal of Humour Research 18 (4), pp. 353-387. https://doi.org/10.1515/humr.2005.18.4.353.

Holmes, M. (2007). What is Gender? Sociological Approaches. Thousand Oaks, CA: SAGE Publications Ltd.

Joke Bank - Sexist Joke. (n.d.). Retrieved October 26, 2017, from Laugh FACTORY: http://www.laughfactory.com/jokes/sexist-jokes/.

Jorgensen, M., \& Phillips, L. J. (2002). Discourse Analysis as Theory and Method. Thousand Oaks, CA: SAGE Publications.

Kotthoff, H. (2006). 'Gender and politics: The state of the art'. Journal of Pragmatics 38, pp. 4-25. https://doi.org/doi:10.1016/j.pragma.2005.06.003.

Kuipers, G. (2015). Good Humour, Bad Taste: A Sociology of the Joke. Berlin: Mouton de Gruyter.

Laineste, L. (2008). 'Politics of joking: Ethnic jokes and their targets in Estonia (1890s-2007)'. Folklore: Electronic Journal of Folklore 40, pp. 117-146.

Lew, R. (1996). An ambiguity-based theory of the linguistic verbal joke in English. Doctoral Thesis, Adam Mickiewicz University.

Lisdiantina, A. (2013). An analysis of the occurrence of sexism in blonde joke websites. Undergraduate Thesis, Sanata Dharma University, Language and Arts Education. $\quad$ Retrieved $12 \quad$ October $2018, \quad$ from https://repository.usd.ac.id/4599/2/091214069 full.pdf.

Martin, R. A. (2007). The Psychology of Humour: An Integrative Approach. Burlington: Elsevier Academic Press.

Masaeli, B., \& Heidari-Shahreza, M. A. (2016). 'A linguistic analysis of Persian online jokes in light of general theory of verbal humour'. Journal of Applied Linguistics and Language Research 3 (7), pp. 230-239.

McGraw, P. (2011, September 14). 'The importance of humour research'. Retrieved November 2, 2017, from Psychology Today: https://www.psychologytoday.com/blog/thehumour-code/201109/the-importance-humour-research.

Mehl, M. R., Esparza, N. R., Slatcher, R., \& Pennebaker, J. W. (2007, August). 'Are women really more talkative than men?'S Science 317, p. 82. doi:10.1126/science.1139940.

Parkins, R. (2012). 'Gender and emotional expressiveness: An analysis of prosodic features in emotional expression'. Pragmatics and Intercultural Communication, pp. 45-54. 
Pasaribu, T. A., \& Kadarisman, A. E. (2016). 'Coding logical mechanism and stereotyping in gender cyber humours'. A Journal of Culture, English Language Teaching \& Literature 16, pp. 22-48. doi:10.24167/celt.v16i1.485

Prentice, D., A. \& Carranza, E. (2002). 'What women and men should be, shouldn't be, are allowed to be, and don't have to be: The contents of prescriptive gender stereotypes'. Psychology of Women Quarterly 26, pp. 269-281.

Ross, A. (1998). The Language of Humour. London: Routledge.

Royo, M., Aldas, J., Kuster, I., \& Vila, N. (2001). 'Sexism and gender role portrayals in Spanish TV commercials'. Retrieved November 20, 2017, from http://www.researchgate.net/profile/Ines Kuester_Boluda/publication.

Shade, A. R. (1996). Licence to Laugh: Humour in the Classroom. Westport, CT: Greenwood Publishing.

Shifman, L., \& Lemish, D. (2009). 'Between Feminism and fun(ny)mism'. Information, Communication \& Society 13 (6), pp. 870-891. doi:10.1080/13691180903490560

Stephens, D. P., \& Phillips, L. D. (2014). 'Freak, gold diggers, divas, and dykes: The sociohistorical development of adolescent African American women's sexual scripts'. Retrieved from http://www.researchgate.com/publication/225572638 Freaks_Gold_Diggers and dykes The sociohistrorical development of dolescent_African_Maerican_women_sexual_scri pts.

Szymanski, D. M., Moffitt, L. B., \& Carr, E. R. (2011). 'Sexual objectification of women: Advances to theory and research'. The Counselling Psychologist 39 (1), pp. 6-38. doi: $10.1177 / 0011000010378402$

Thomae, M., \& Pina, A. (2015). 'Sexist humour and social identity: The role of sexist humour in men's in-group cohesion, sexual harassment, rape proclivity, and victim blame'. Humour: International Journal of Humour Research 28 (2), pp. 187-204. https://doi.org/10.1515/humour-2015-0023

Tosun, S., Faghihi, N., \& Vaid, J. (2018). 'Is an ideal sense of humour gendered? A crossnational study'. Frontiers in Psychology, 9 (Feb), pp. 1-8. https://doi.org/10.3389/fpsyg.2018.00199.

Tsakona, V. (2009). 'Language and image interaction in cartoons: Towards a multimodal theory of humour'. Journal of Pragmatics 41, pp. 1171-1188. doi:10.1016/j.pragma.2008.12.003

Verhellen, Y., Dens, N., \& Pelsmacker, P. d. (2014). 'A longitudinal content analysis of gender role portrayal in Belgian television advertising'. Journal of Marketing Communications 22, pp. 1-19. doi:10.1080/13527266.2013.871321

Weatherall, A. (2002). Gender Language and Discourse. New York: Routledge.

Wu, C. L., Lin, H. Y., \& Chen, H. C. (2016). 'Gender differences in humour styles of young adolescents: Empathy as a mediator'. Personality and Individual Differences 99 (162), pp. 139-143. https://doi.org/10.1016/j.paid.2016.05.018. 